\title{
EFFECT OF PHOSPHOROUS FERTILIZER AND FIVE VARIETIES ON THE QUANTITY AND QUALITY OF SUGAR BEET (Beta Vulgaris L.)
}

Salih .M. Al-Rashidi

Dept . of Soil and Water, Collage Agric. and Forestry,Mosul univ. Iraq

\section{ABSTRACT}

A field Experiments in two agricultural locations were carried out to evaluate three levels of phosphorous fertilizer $(60,80,120) \mathrm{Kg} \mathrm{P} / \mathrm{ha}$, as super phosphate and five varieties of sugar beet, Monogerm (Vero, Rosana, Rosa) and, Multigerm (Gitane, Monterosa). Results showed the yield of root (ton/ha) increased significantly as the fertilizer increased, which gives $(20.3 \%, 24.6 \%)$ when compared with first level added of phosphorous fertilizer respectively , The root sugar also increased as compared to the first level $(0.65 \%, 0.89 \%)$ respectively in both locations, Monogerm (Vero, Rosana, Rosa) gave a high yield of sugar and purity when compared with the Multigerm ,Vero surmount to the others Monogerm Rosana and Rosa at the two locations .So phosphorous fertilizer and the Monogerm of the sugar beet increased the quantity and Improved quality at the two locations under Iraqi conditions

\section{INTRODUCTION}

Sugar beet (Beta Vulgaris L.) related to the Chenopodiaceae family is an important plant in sugar production. Sugar is considered as consuming substance in the world societies. Even the Molasses, which is the main byproduct, filtered substance of sugar industry is an important matter used for animal's nutrition, in addition to obtain alcohol and acetone as sub products (cattanach et al., 1993). Sugar industry started in Iraq after building a factory in Mosul in Northern Iraq at the begging of the sixteenth of the last decade century. Many problems faced this industry from the beginning and continued till now. The main problems were how to in crease the yield and the quality, By facing the mechanization problems, the fertilizer recommendations and the suitable varieties of sugar beet which gives higher quantities and good qualities under Iraqi conditions specially during spring sowings (Alrashidi 2001, Kuldip, 2009).Sugar beet quality involves two concepts: the percent sucrose, and the level of impurities in the roots, both of which affect sucrose extraction by the processor. Production of high quality sugar beets is especially important to growers whose payment is based on the extractable sucrose content of their beets (Shallenbarger 1995; Draycott and Christonson, 2003; ,Ancuta, 2008). Plants need Phosphorus for growth, utilization of sugar and starch, photosynthesis, nucleus formation and cell division, fat, and albumen formation. Phosphorus compounds are involved in the transfer and storage of energy within plants. Energy from photosynthesis and the metabolism of carbohydrates is stored in phosphate compounds for later use in growth and reproduction ( Barker and Pilbeam, 2007 Marchnar, 2008 ), Phosphorus is readily translocated within the plants, moving from older to younger tissues as the plant form cells and develops roots, stems and leaves. Sugar roots yield in check plot (No P fertilizer) was about $56.97 \mathrm{ton} / \mathrm{ha}$, while increased to 84.4 ton/ha after the addition of $75 \mathrm{~kg} \mathrm{P} 2 \mathrm{O} 5 / \mathrm{ha}$ (Smith et al. 2002).Adequate $\mathrm{P}$ results in rapid growth and earlier maturity, which 
is important in areas where frost is a concern. Frequently, the quality of vegetative growth is improved. A good supply of P to sugar beet has been associated with increased roots growth, which means the plant can explore more soil for nutrients and moisture. These will reflect to improve quantity and quality of sugar beet other wise a deficiency of P will slow overall plant growth.(Mengle and Armstrong, 1987; Jaszczolt, 2000; Lamb et al. 2001), Varieties consider as important factor witch depend on the environmental conditions (Abdal, 2005). The main problems of using phosphate fertilizers in calcareous soils is the availability $\mathrm{P}$ to plants uptake and utilization impaired in these soils due to the formation of poorly soluble (Ca-P) minerals (Hopkins and Ellsworth, 2005). So adding fertilizer P at normal rates and choosing the suitable Crops and Varieties may incurs these problems to reach the economic yields with higher Quantities and best Qualities of Sugar Beet productions. The present study might give some answers about these questions regarding the phosphate fertilization requirements for Iraqi calcareous soils.

\section{MATERIALS AND METHODS}

A field experiment conducted in two locations in the Iraqi fields the first at Hawiga (L1) About $90 \mathrm{Km}$ East- North Mosul city and the other in Rabeia (L2) about $80 \mathrm{Km}$ North- West of Mosul city, the two locations considered as a famous area in sugar beet production. Some chemicals and physical soil properties of these regions are showed in Table (1) Routine Analysis' - Available $\mathrm{P}, \mathrm{K}$ and $\mathrm{N}$ with total $\mathrm{CaCO}_{3}$ and $\mathrm{P}^{\mathrm{H}}$ with Organic matter ( page etal 1982 ) the experiment designed as a Split plot with ( R.C.B.D ) in a factorial treatments, Three levels of phosphate fertilizer levels (PFL) P1 , P2 and P3 $(60,90,120) \mathrm{Kg}$ P/ha respectively, in a main plot (there is no control (Zero P ) treatment- because this crop not growing with out fertilizers) Varieties (Vero, Rosa and Rosanna ) and (Gitan, Monterosa ) Monogerm (Mon.) and multi germ (Mul.) respectively, in a Secondary plots.

Table (1): Physical and chemical properties of soils L1, L2 Location under study

\begin{tabular}{|l|c|c|c|c|}
\hline \multirow{2}{*}{ Properties } & \multicolumn{2}{|c|}{ Soil L1 } & \multicolumn{2}{c|}{ Soil L2 } \\
\cline { 2 - 5 } & \multicolumn{2}{|c|}{ Depth Cm } & \multicolumn{2}{c|}{ Depth Cm } \\
& $0-15$ & $15-30$ & $15-30$ & $0-15$ \\
\hline Texture & SL & SL & CL & CL \\
\hline Available N (PPm) & 50.4 & 65.2 & 55.5 & 70.3 \\
\hline Available K (PPm) & 85.6 & 120.4 & 71.5 & 96.6 \\
\hline Available P (PPm) & 2.5 & 2.6 & 3.5 & 4.7 \\
\hline Organic M. \% & 0.63 & 0.97 & 0.14 & 0.47 \\
\hline $\mathrm{CaCo}_{3}$ Total \% & 22.8 & 28.4 & 15.7 & 22.6 \\
\hline $\mathrm{Ec} \mathrm{dS} \mathrm{m/m}$ & 2.7 & 3.4 & 2.4 & 2.6 \\
\hline $\mathrm{P}^{\mathrm{H}} 1: 1$ & 8.0 & 8.2 & 8.1 & 7.8 \\
\hline
\end{tabular}

Sowing date L1 and L2 $(9,12$. April) respectively, the seeds was sowing by a developmental seed sowing model 2001 after plowings and leveling the field Seeds were sowing in a same depth at $2.5 \mathrm{Cm}$, the line long about 50 Meters and the Distance between lines are $30 \mathrm{Cm}$, between plants about $12 \mathrm{Cm}$ the field irrigated by sprinkler irrigation, Phosphate fertilizer levels (PFL) added at the sowing with The first part of the Nitrogen fertilizer as Urea $140 \mathrm{Kg} / \mathrm{ha}$, weeds control by the 
Pyramine, the roots harvested in the (28 Sept). and (4 0ct.) for the two location respectively, (DWR) the weight of air dry roots /plant) and (DWL) Weigh of air dry vegetative parts / plant were taken at harvest, oven dry weight for roots (ODWR) and oven dry weight for leaves (ODWL) had been taken. Samples were sent to Mosul sugar company to measure and determine the quality of roots (Total Soluble Salt (TSS), Sugar percent (SP) and (PP) .purity percent) then the all plots harvested for each treatment to obtain the Total roots yield (TY) as Ton/ha, The experiment analysis by Duncan probability 0.05 to identified a significant (Sig) treatment.

\section{RESULTS AND DISSCUTION}

Sugar beet quantity ,Table (2) showed the (DWR) ( $\mathrm{Kg} /$ plant) are increase significantly with the phosphate fertilizer(PFL ) increase in two locations (L1, L2) under study. increment percentage( IP) as compared to the first level of adding phosphate are $(34.3,85.5 \%)$ and $(14,61,9 \%)$ for $(\mathrm{L} 1, \mathrm{~L} 2)$ respectively. the reasons of these results related to the effect of $\mathrm{P}$ in biotic process in plant like cell division and active transport carbohydrate material from leaves as source to the root as a sink (Krauss 2003 , and Draycott 2006).

Phosphorus compounds are involved in the transfer and storage of energy within plants ,for these purposes the (PFL ) increase the DWR/plant. these results showed the L1 is more response to adding fertilizer than L2 because the available $\mathrm{P}$ in the first Location lower than L 2 table (1) also most soil properties for L1 location is better than L2 location like available nitrogen and low electric conductivity with suitable soil texture for sugar beet. these results agreed with (.Lamb et al 2001) they suggested to add phosphorous fertilizer $(100-12.5) \mathrm{kg}$ $\mathrm{P}_{2} \mathrm{O} 5 /$ ha , when the soil test by Olsen Method between (3 - !5 ) ppm respectively. The results corresponded with albadrani 2006 she found ,the weight of root /plant between(1.12 to 1.35$) \mathrm{kg} /$ root in two locations in Iraq Vero variety gave highest weight of roots / plant at the two locations, so this variety can be considered because having high genetically properties .and suitable for Iraqi conditions . the highest weights of roots were obtained from the interaction between the third level of phosphate with Vero Variety are (2.14and 2.36 ) $\mathrm{kg} /$ plant fore L1 and L 2 respectively. Table (3,) showed the (PFL) increase significantly the (ODWR) in two locations when we compared to the first level, the (IP) were $(6.9,41.8 \%)$, and $(6.5,41.3 \%)$ for the (L1,L2 ) respectively the reasons to get these results because ( PFL ) affect the air dry weight roots / plant and these reflected to the oven dry more over, Plants need phosphorus for growth, utilization of sugar and starch, photosynthesis, nucleus formation and cell division, fat and albumen formation (Roy etal 2006). Results declare No significant difference between the Varieties (Vero , Rosa and Rosanna) which are a Mongerm varieties these can be suitable and adapted for these locations under studied, Results concerned with many researches that (Mon) having a good growing properties. Alrashidi 2003, and Abdal 2005. Fig (1) showed the air dry weights of vegetative part of plant (D WL) of the two locations, phosphate increase significantly as the fertilizer increase which these results agreement with the weight of the roots / plant, the (IP) are (9.6,14.9\%) and $(11.9,16.4 \%)$ when compared to the first level of phosphate fertilizer for the two locations respectively. The reasons of these results depend on $\mathrm{P}$ increasing the biotic processes in plant and its up take of nutrients to increase Mobil nutrients in plant which improve (LAI) and increase the light absorbance by leaves which reflect on 
photosynthesis's processes, Results showed the impotents of the leaves which consider a factory of the sugar production for sugar beet, and then storage in the root (Draycott 2003. While the effect of varieties on Air dry weights (DWR), the figs showed there was no significant difference between most varieties in the two location especially on the Mongerm in spite of the L2 gave a high weight than L1, the interaction between P levels and Varieties were from P3 with Vero (0.9 and $0.69) \mathrm{kg} /$ plant fore L1, L2 respectively.

Table (2): Effects of phosphate fertilizer (PF) and varieties (VR) on Weight of Root /plant (DWR) on two locations L1, L2 respectively

\begin{tabular}{|c|c|c|c|c|}
\hline \multirow{2}{*}{ varieties } & \multicolumn{3}{|c|}{ phosphate fertilizer $\mathrm{Kg} \mathrm{P} /$ ha } & \multirow{2}{*}{$\begin{array}{l}\text { Effect of } \\
\text { varieties }\end{array}$} \\
\hline & 60 & 90 & 120 & \\
\hline Vero & 0.94 & 1.43 & 2.14 & $1.5 \mathrm{a}$ \\
\hline Rosa & 0.86 & 0.94 & 1.23 & $1.01 \mathrm{c}$ \\
\hline Rosanna & 0.98 & 1.3 & 1.67 & $1.32 \mathrm{~b}$ \\
\hline Gitan & 0.66 & 0.94 & 1.36 & $0.98 \mathrm{c}$ \\
\hline Montrose & 0.69 & 0.88 & 1.3 & $0.98 \mathrm{c}$ \\
\hline Vero & $\begin{array}{l}0.83 \mathrm{c} \\
1.22\end{array}$ & $\begin{array}{l}1.09 \mathrm{~b} \\
1.62\end{array}$ & $\begin{array}{l}1.54 \mathrm{a} \\
2.36\end{array}$ & 1.73 \\
\hline Rosa & 1.21 & 0.98 & 1.46 & 1.22 \\
\hline Rosanna & 1.2 & 1.42 & 1.84 & $1.43 \mathrm{~b}$ \\
\hline Gitan & 0.87 & 0.98 & 1.42 & $1.04 \mathrm{~d}$ \\
\hline Montrose & 0.73 & 0.92 & 1.6 & $1.08 \mathrm{~d}$ \\
\hline $\begin{array}{c}\text { Effect } \\
\text { of Fertilizer }\end{array}$ & $1.03 \mathrm{c}$ & $1.18 \mathrm{~b}$ & $1.74 \mathrm{a}$ & \\
\hline
\end{tabular}

Table(3) :Effects of phosphate fertilizer (PF) and varieties (VR) on oven dry Weight of root (ODWR ) Kg /plant on two Regions L1, L2 respectively

L1

\begin{tabular}{|c|c|c|c|c|}
\hline \multirow{2}{*}{ varieties } & \multicolumn{3}{|c|}{ Phosphate fertilizer Kg P/ ha } & \multirow{2}{*}{$\begin{array}{c}\text { Effect of } \\
\text { varieties }\end{array}$} \\
\cline { 2 - 4 } & 60 & 90 & 120 & $0.52 \mathrm{a}$ \\
\hline Vero & 0.41 & 0.52 & 0.64 & $0.51 \mathrm{a}$ \\
\hline Rosa & 0.38 & 0.49 & 0.66 & $0.46 \mathrm{a}$ \\
\hline Rosanna & 0.28 & 0.48 & 0.61 & $0.41 \mathrm{a}$ \\
\hline Gitan & 0.26 & 0.39 & 0.57 & $0.37 \mathrm{~b}$ \\
\hline Montrose & 0.24 & 0.38 & 0.56 & $0.61 \mathrm{a}$ \\
\hline \hline & $0.34 \mathrm{c}$ & $0.46 \mathrm{~b}$ & $0.61 \mathrm{a}$ & $0.56 \mathrm{a}$ \\
\hline Vero & 0.57 & 0.57 & 0.69 & $0.56 \mathrm{a}$ \\
\hline Rosa & 0.51 & 0.57 & 0.59 & $0.53 \mathrm{a}$ \\
\hline Rosanna & 0.46 & 0.54 & 0.69 & $0.45 \mathrm{~b}$ \\
\hline Gitan & 0.42 & 0.51 & 0.68 & \\
\hline Montrose & 0.32 & 0.42 & 0.62 & \\
\hline $\begin{array}{c}\text { Effect } \\
\text { of Fertilizer }\end{array}$ & $0.46 \mathrm{~b}$ & $0.48 \mathrm{~b}$ & $0.65 \mathrm{a}$ & \\
\hline
\end{tabular}



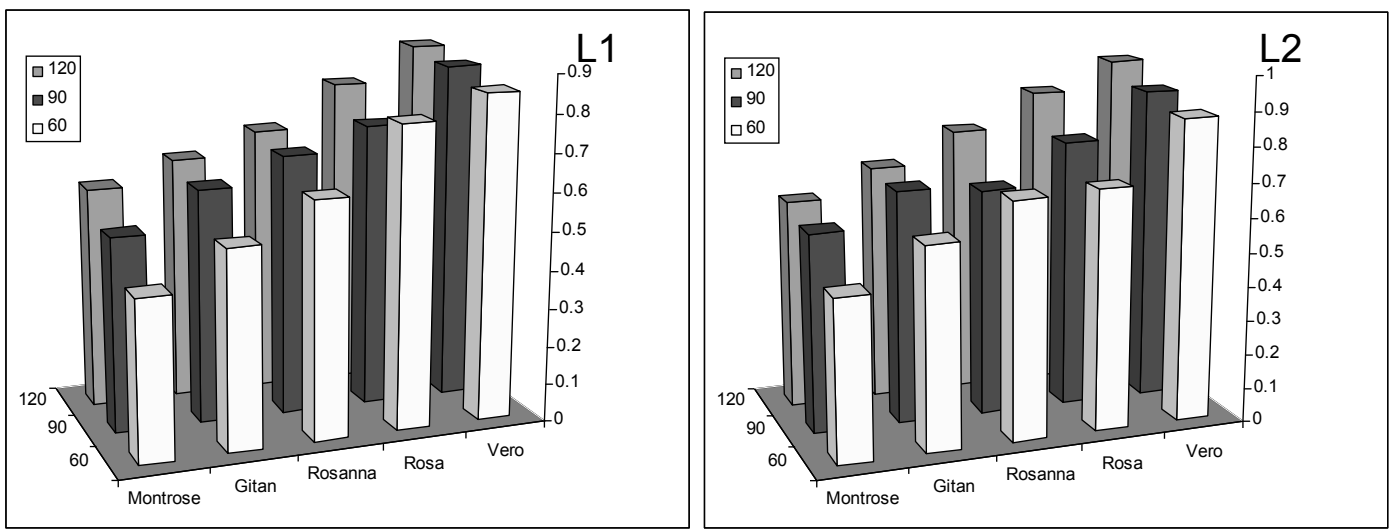

Fig (1) : Effects of phosphate fertilizer (PF ) and varieties (VR ) on Air dry Weight of leaves (DWL ) Kg/plant on two Regions L1 ,L2 respectively

Results showed in (Fig 2) L1 and L2 there were no significant difference between P2 and P3 in (ODWL) / plant, there were no differentiated between the (Mon) Vero and Rosa in this property of leaves, interaction to get a high yield of (ODWL) However the Vero with P3 (0.29 and 0.3) Kg/plant for L1 and L2 respectively .Table. (4) Showed (PFL) gave a high significant effect on the total yield To/ha (TY) as the fertilizer increase the (IP) as compared to the first level 60 $\mathrm{Kg} / \mathrm{ha}(6.5 \%, 10.6 \%)$ and $(0.8 \%, 0.7 \%)$ for the two locations respectively these results related to increase the (DWR) as a result of increase (LAI), Leaf Area Index these consistent with the results (alrashidi 2001 and, (Lamb et al 2001) and Albadrani 2006) that (TY) reaches (82- 90) ton / ha with good managements and suitable soil fore sugar beet, As consistent with the previous results in L1 and L2 the Mon. (Vero ,Rosa ,and ,Rosanna) also gave a high significant results compared to the others varieties used in these experiments . the interactions between these treatments in the (TY) of roots Ton /ha are from the P3 with the Vero (86.2 and 88.92) Ton / ha roots for L1 and L2 respectively.
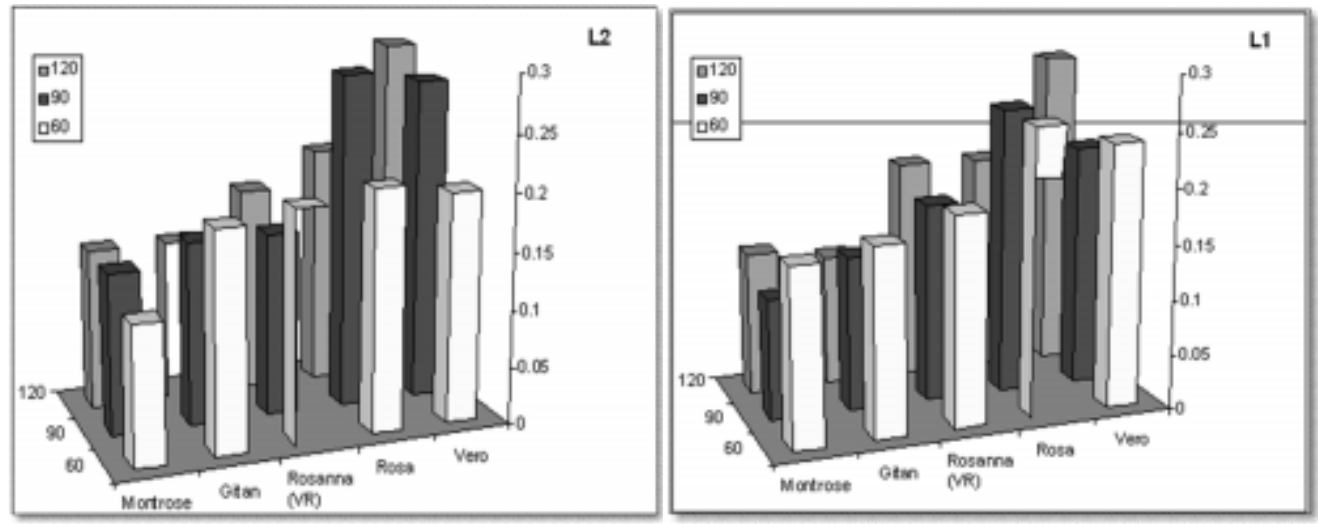

Figs (2) : Effects of phosphate fertilizer (PF) and varieties (VR ) on Weight of oven dry leaves (ODWL) Kg /plant on two Regions L1 ,L2 respectively

So from these results of (TY)Ton /ha conclude firstly ( Sugar beet not growing without fertilizer to reach an economic yield in these two locations under Iraqi conditions, second Vero variety gave a high significant results with the two 
locations under study And confirmed this variety a suitable for sugar beet growing on these locatins under studied. How ever sugar beet require a high level of management and grown on more productive soils (Sims and Smith 2002), other wise the soil types and constituents (organic matter, clay content ,percent of lime) these have a decided effect on the availability of phosphorous that effectuated sugar beet yield, ( Brosba et al 2002)

Sugarbeet Quality Figs (3) and Tables $(5,6,7)$ showed some measurements on quality of the roots for sugar beet (total soluble salt (TSS) with a sugar percent (SP) and purity percent (PP) more over we measure white sugar (WS) after sending roots sample to Mosul sugar beet company, from these Figs (5 and 6) the (PFL) increase the (TSS) but not in significant affect , also there were some difference between varieties but not reach a Sig. for the two locations L1 and L2, the interaction between the treatment (Rosa and Vero ) with P 3 in these L1 and L 2 $(20.4 \%$ and $20.2 \%)$ respectively.

Table(4) :Effects of phosphate fertilizer ( PF ) and varieties( VR) on total yield of root ( TY ) Ton/ha on two Regions L1, L2 respectively

\begin{tabular}{|c|c|c|c|c|c|}
\hline \multirow{7}{*}{ L1 } & \multirow[t]{2}{*}{ varieties } & \multicolumn{3}{|c|}{ Phosphate fertilizer Kg P/ha } & \multirow{2}{*}{$\begin{array}{l}\text { Effect of } \\
\text { varieties }\end{array}$} \\
\hline & & 60 & 90 & 120 & \\
\hline & Vero & 78.69 & 84.69 & 88.92 & $84.1 \mathrm{a}$ \\
\hline & Rosa & 77.63 & 79.22 & 86.43 & $81.09 \mathrm{a}$ \\
\hline & Rosanna & 75.3 & 78.85 & 83.76 & $79.18 \mathrm{~b}$ \\
\hline & Gitan & 78.1 & 78.31 & 80.33 & $77.91 \mathrm{~b}$ \\
\hline & Montrose & 76.83 & 78.63 & 74.69 & $76.71 \mathrm{c}$ \\
\hline \multirow{9}{*}{ L2 } & & $77.38 \mathrm{~b}$ & $76.71 \mathrm{~b}$ & $82.82 \mathrm{a}$ & \\
\hline & \multirow{2}{*}{ varieties } & \multicolumn{3}{|c|}{ Phosphate fertilizer Kg P/ ha } & \multirow{2}{*}{$\begin{array}{l}\text { Effect of } \\
\text { varieties }\end{array}$} \\
\hline & & 60 & 90 & 120 & \\
\hline & Vero & 76.4 & 80.22 & 86.2 & $80.94 \mathrm{a}$ \\
\hline & Rosa & 74.12 & 76.16 & 79.98 & $77.42 \mathrm{~b}$ \\
\hline & Rosanna & 72.1 & 74.72 & 77.41 & $77.74 \mathrm{~b}$ \\
\hline & Gitan & 68.43 & 72.84 & 76.72 & $72.66 \mathrm{c}$ \\
\hline & Montrose & 66.41 & 74.2 & 72.69 & $71.1 \mathrm{c}$ \\
\hline & $\begin{array}{c}\text { Effect } \\
\text { of Fertilizer }\end{array}$ & $71.4 \mathrm{c}$ & $76.03 \mathrm{~b}$ & $79 \mathrm{a}$ & \\
\hline
\end{tabular}

We know about (TSS), should attached with the sugar percent to be desirable in production of sugar beet (alrashidi 2001, albadrani 2006), Tables (8 and 9) showed sugar percent (SP) which is the most important property of the roots of sugar beet increase with the (PFL) increase in two locations, the (IP) are (4.8\%, $11.2 \%),(-10.9 \%, 17.1 \%)$ for their locations receptively, when compared with first level of fertilizer, from these results showed L2 is more responded than L1 in (SP) the most important factor which affect the (SP) are temperatures at night during the mature of plant before 30 days of harvesting (Draycott 1996) These results were consistent with the finding obtained by), Marvon (1997) and Al - 
Rashidi (2001) they found the percentage of sugar in root reach about $17 \%$ which increase significantly with (PFL) (jaggad 2008).

Results indicated the Vero varieties was to surpass the all varieties growing in the two locations under study, the interaction to get highest percentage from Vero with P 3 are $(16,0 \%$ and $16.4 \%)$ respectively.

Tables (10 and 11) showed (PF L) increase the purity percentage of the roots (PP) significantly as the fertilizer increase, the (IP) were (14.4\%,22.4\%) and $(11.1 \%, 20.4 \%)$.for these locations respectively as compared to the first level of the phosphate fertilizer $60 \mathrm{Kg} / \mathrm{Pha}$. Results are agreed with the results obtained by (Ibrahim et al 2005, Albadrani 2006) they found also the Vero varieties to surpass the all varieties growing in the their studied, which certainly attributed to their genetically properties for growing in these locations.
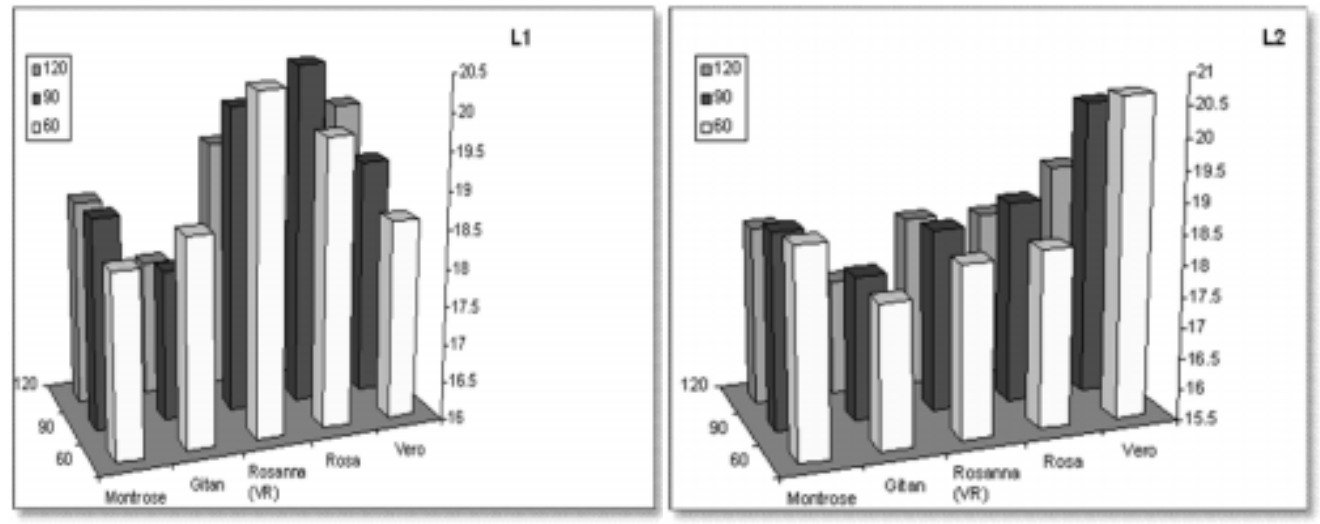

Fig (3): Effects of phosphate fertilizer (PF ) and varieties (V) on percent of total soluble salt (TSS \% ) on two Regions L1 ,L2 respectively.

The interaction for (PP \%) were between (VR ) and (PFL ) , found Vero and P3 in L2 and Rosa with P3 In L1 (86.4 \% and $87.7 \%$ ) Respectively .Tables (12 and 13) showed white sugar (WS) affect significantly by (PFL) especially when compared to first level in L1 and L2 treatments. The (I P) Were (5.3\%, $10.9 \%)$ and $(5.4 \%, 12.5 \%)$ for P2 and P3 Respectively.

In general (PFL) application increase (SP) and (PP) with corresponding to increase (DWR) and (WS) from these results we found $90 \mathrm{~kg} \mathrm{P} / \mathrm{ha}$ was optimum rate to obtain higher yields and better quality of sugar beet in two locations under studied with Iraqi conditions). Vero variety is significantly increase most of properties in yield and Qualities for Sugar beet as compared to the other varieties under study at the two locations (Ibrahim et al 2005) they found varieties differ in yields and quality .these results agreed with Smith and Smith (1997) they showed weights of white sugar related with phosphate fertilizers and with Saccomani and Stevanato (2007) they found(Mon) seed gave a high results in white sugar than the (Mult) seeds theses results clearly showed positive effect of $P$ fertilizer application increase leaves areas and root weight of the crop which reflect on beet yield for sugar content and sugar yield on theses locations under Iraqi environments . 
Table (5) : Effects of phosphate fertilizer(PFL ) and varieties( VR ) on sugar percent (SP) on two Regions L1,L2 respectively

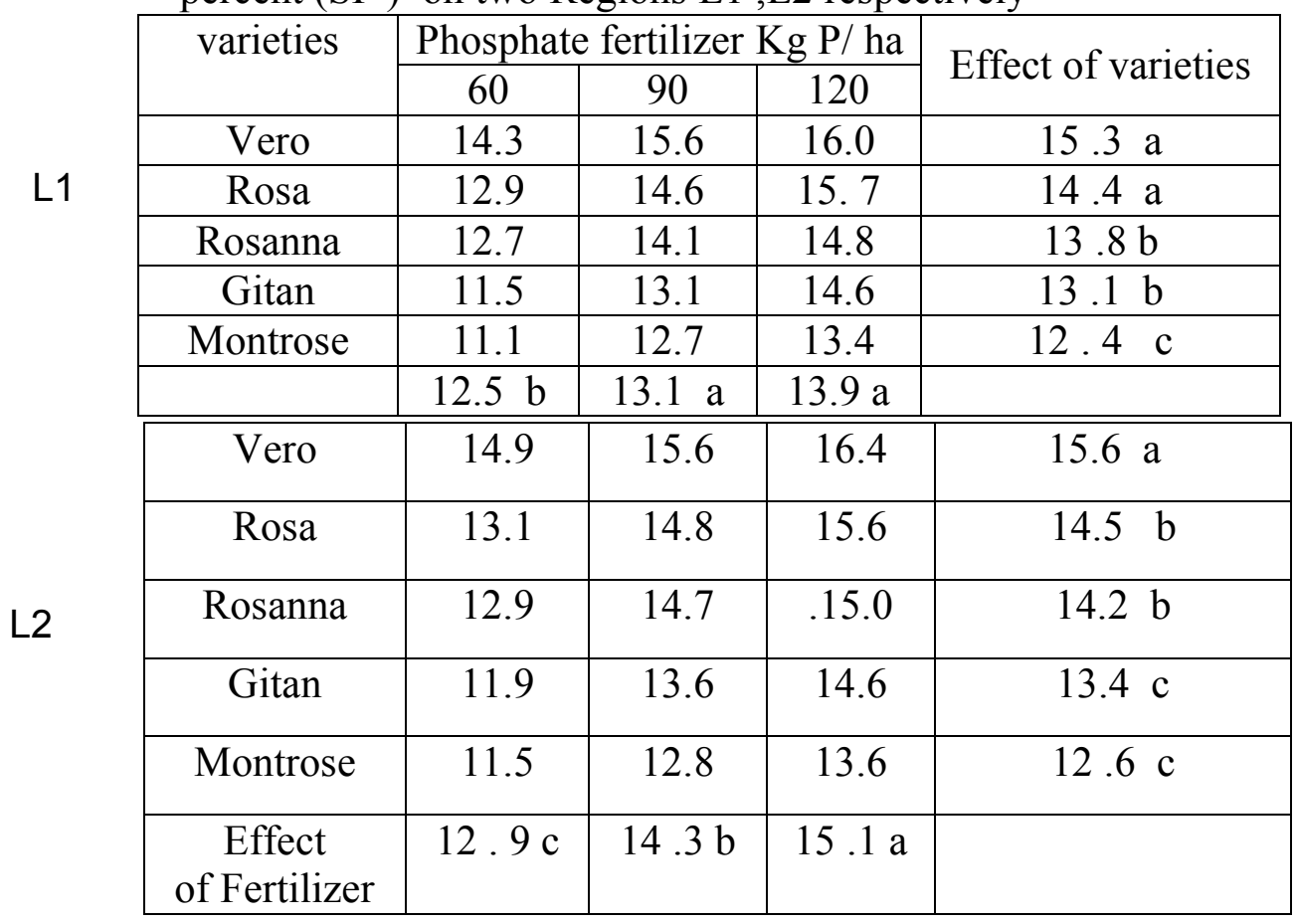

Table (6) :Effects of phosphate fertilizer (PFL) and varieties (VR) on purity percent (PP) on two Regions L1, L2 respectively.

L1

\begin{tabular}{|c|c|c|c|c|}
\hline \multirow{2}{*}{ varieties } & \multicolumn{3}{|c|}{ Phosphate fertilizer Kg / ha } & \multirow{2}{*}{ Effect of varieties } \\
\cline { 2 - 5 } & 60 & 90 & 120 & $79.8 \mathrm{a}$ \\
\hline Vero & 76.8 & 81.5 & 81.2 & $74.5 \mathrm{~b}$ \\
\hline Rosa & 65.2 & 71.2 & 87.1 & $69.7 \mathrm{c}$ \\
\hline Rosanna & 62.1 & 70.4 & 76.6 & $72.1 \mathrm{~b}$ \\
\hline Gitan & 61.3 & 72.8 & 82.1 & $69.5 \mathrm{c}$ \\
\hline Montrose & 60.3 & 76.6 & 71.6 & $78.4 \mathrm{a}$ \\
\hline & $65.1 \mathrm{c}$ & $74.5 \mathrm{~b}$ & $79.7 \mathrm{a}$ & $78.4 \mathrm{a}$ \\
\hline \hline Vero & 72.1 & 76.8 & 86.4 & $77.4 \mathrm{a}$ \\
\hline Rosa & 71.2 & 78.7 & 85.4 & $75.6 \mathrm{a}$ \\
\hline Rosanna & 70.6 & 79.6 & 81.9 & $67.8 \mathrm{~b}$ \\
\hline Gitan & 66.7 & 76.2 & 83.9 & \\
\hline Montrose & 61.1 & 68.4 & 73.9 & \\
\hline $\begin{array}{c}\text { Effect } \\
\text { of } \\
\text { Fertilizer }\end{array}$ & $68.3 \mathrm{c}$ & $75.9 \mathrm{~b}$ & $82.3 \mathrm{a}$ & \\
\hline
\end{tabular}


Table (7) : Effects of phosphate fertilizer (PFL) and varieties (VR) on white sugar (WS) on two Ton/ha Regions L2, L1 respectively.

\begin{tabular}{|c|c|c|c|c|c|}
\hline & \multirow{2}{*}{ varieties } & \multicolumn{3}{|c|}{ Phosphate fertilizer Kg P/ha } & \multirow{2}{*}{$\begin{array}{l}\text { Effect of } \\
\text { varieties }\end{array}$} \\
\hline & & 60 & 90 & 120 & \\
\hline \multirow{5}{*}{ L1 } & Vero & 1.434 & 1.572 & 1.623 & $1.543 \mathrm{a}$ \\
\hline & Rosa & 1.321 & 1.342 & 1.463 & $1.375 \mathrm{~b}$ \\
\hline & Rosanna & 0.689 & 0.884 & 0.962 & $0.912 \mathrm{c}$ \\
\hline & Gitan & 0.541 & 0.582 & 0.599 & $0.574 \mathrm{~d}$ \\
\hline & Montrose & 0.432 & 0.469 & 0.453 & $0.451 \mathrm{e}$ \\
\hline \multirow{7}{*}{ L2 } & $\begin{array}{c}\text { Effect } \\
\text { of Fertilizer }\end{array}$ & $0.919 \mathrm{c}$ & $0.968 \mathrm{~b}$ & $1.02 \mathrm{a}$ & \\
\hline & Vero & 1.36 & 1.335 & 1.423 & $1.328 \mathrm{~b}$ \\
\hline & Rosa & 1.23 & 0.642 & 0.653 & $1.318 \mathrm{~b}$ \\
\hline & Rosanna & 0.662 & 0.539 & 0.614 & $0.558 \mathrm{c}$ \\
\hline & Gitan & 0.521 & 0.536 & 0.611 & $0.526 \mathrm{c}$ \\
\hline & Montrose & 0.432 & $0.908 \mathrm{~b}$ & $0.969 \mathrm{a}$ & \\
\hline & $\begin{array}{c}\text { Effect } \\
\text { Of Fertilizer }\end{array}$ & $0,861 \mathrm{c}$ & $0,908 \mathrm{~b}$ & 0.969 a & \\
\hline
\end{tabular}

تاثير التسميد الفوسفاتي وخمسة اصناف من البنجر السكري( Beta Vulgaris L ) في الحاصل والنوعيه

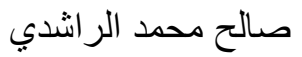
قسم علوم التربه و المياه _كلية الزراعه والغلبات - جامعة الموصل / العراق

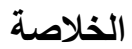

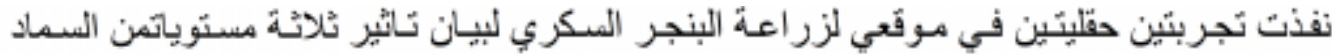

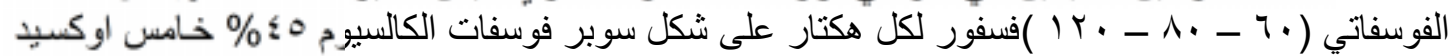
الفسفور مع خمسة اصناف من البذور المستوردة حديثا ، احادي الجنين (Vero, Rosana, Rosa) / اهكتار ازداد بصوره معنويه

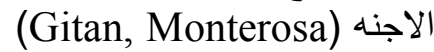

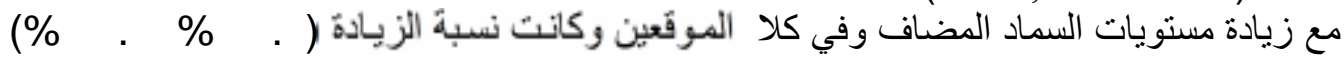

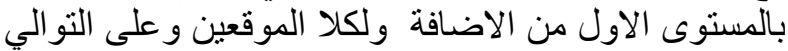

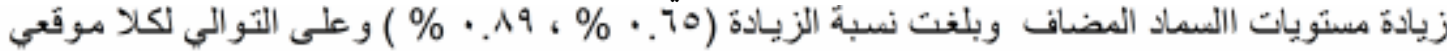

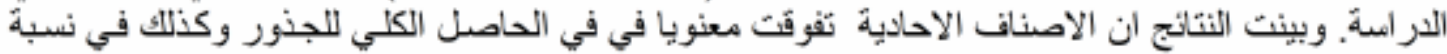

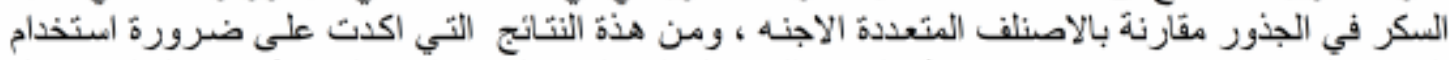

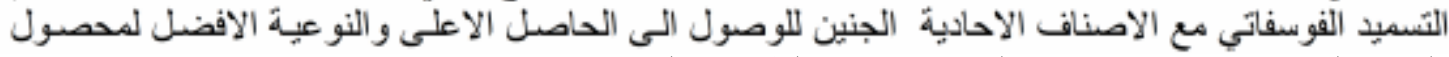
البنجر السكري وفي كلا موقعي الدراسة وتحت الظروف الأنس العر اقية .

\section{REFRENCES}

Ancuta RO., E.Luca, S. Barsan and G. Serban (2008). Experimental result researches the crop technology sugar beet irrigation system. Vol 65 No 2, Bulletin of university of Agr. Sc. and veterinary M. C-N Horticulture

Al-Rashidi, S.M.( 2001 ) Effect of NP fertilizer on the quantity and quality of sugarbeet .PH.D Thesis Mosul Univ of Mosul, Iraq .

Al-Rashidi .S. M., (2003) Effect of Boron fertilized levels and times sprayed on yield and Quality of Sugar beet .Tikrit agr. J . vol 3. 
Abdal , S.A. (2005 )Effect of phosphorus fertilizer level in growth and yield and some varieties of sugarbeet . Msc. Thesis Mosul Unv.not published -Iraq.

Albadrani .w.a,(2006). Effect of potassium and Boron on yield and Qualitys of Sugarbeet (Beta vulgaris L)PH.D,thesis.Mosul Univ, not published -Iraq

Barker and prlbeam . hand book of plant nutrition (2007).boca raton FL,CrC press.613 pp.

Cattanach. A, W. C. Dahnke, C. fanning (1993). fertilizing sugarbeet. Sugarbeet Specialist, NDSU \& U of MN Extension Services sf-714.

Cattanach A.G. Dexter, and E.S. Oplinger (1991) Sugarbeet extenstion sugarbeet specialist ,North Dokota .bulletin537 06-July.

Draycott, A.P. (1996). Fertilizing for yield and quality sugar beet. Bull 15 (p). Basel, Switzerland

Draycott,A.P (2006) Sugarbeet, Oxford -Blackwell Publishing (2006) pp,474 ISBN $10: 1-4051-1911-X$

Draycott ,A.P and D . R Christenson (2003), Nutrients fore Sugar beet Production Publication :Oxon, UK ,Cambridge , MA CABI .

Hopkins. B., and J. Ellsworth (2005) .phosphorus availability with alkaline/calcareous soil western nutrien management conference. 2005.. vol.6. salt lake city, ut

Ibrahim, M.M., Kh.A.O. El-Aref and A.S Abo El-Hamd ( 2005) Effect of nitrogen and phosphorus fertilization on yield and quality effect of nitrogen and phosphorus fertilization on yield and quality of two sugar beet varieties under assuit governorate condition. Zagazig J. of Agr. Res.Vol :32 pp (411-417)

Jaszczolt, E. (2000) Sugar Beet fertilization with phosphorous In relation to the richness of soil in available phosphorus. Gazeta-Cukvolwnicza , 106(4):72-73.

Jaggard .K.W.( -2008) . Effects of soil density on yield fertilizer requirement of sugar beet Annals of applied Biology volume 86, pages 301-312

Krauss, A.(2003) . Important of balanced fertilization to meet the nutrient workshop 1-2 Dec. demand of food crops.

KuLdip ,K ., C. J. Rosen ,S . Gupta and M. McNearney ( 2009) Land Application of Sugar beet :Effect On Nitrogen Mineralization and Crop Yield . Soil Sc. Soc .Am . Vol:38 (1) 319-328.

Lamb j.A, A L. Sims, L .J. Smith, and G W. Rehm . (2001) Fertilizing Sugar Beet in Minnesota and North Dakota . Extenstion of minnesotaand North dakota.

Mengel, E.A. and M.S Armstrong (1987). The absorption and Physiological roles of Plant K in the Sugar Beet plant withreference to the function of $\mathrm{Na}$ and $\mathrm{Mg}$. International Institute for suger Beet Research.

Marvon.,B.Holly Sugar Beet Production Meetings.( 1997 ). Sugar Beet Variety Trial Results, Optimizing Weed Control in Sugar Beets. Madras, Prineville, OR. January 23, 24.

Marchner,H. (1996). Mineral Nutrition of higher plant 2nd Edition Academic press.

Page, A.L ; R.H. Miller and D.R keeney (1982). Method of soil Analysis, part 2Chemicla and biological propertie. AM. Soe.

Argon. Inc Publisher, Madison, Wisconsin U.S.A. Popescu, C; M. Sirbu and D. Ailincai (1994). Energy efficiency in Fertilizer applications to Maize and 
Sugar Beet under the conditions at Podu - Lloaiei, Lasi, CercetariAgronomice in Molodora.25(1):145-150.

Prosba U, S .Uprawy and R, Rolnicza (2006), Effect of fertilization on contenand accumulation of phosphorus and productivity of sugar beet Journal of Element logy 25: 50-375.

Roy ,R.N.,A.fink and G.J Blank(2006) .Plant Nutrition for Food Security IFA publishing -france.

Smis, A.L and L.L. Smith (1997). Phosphorus dynamic affecting Suger Beet.Sugar Beet Research and Extension report28:196.

Sims A.L., and J.Smith (2001) . Early grow th response of sugarbeet to fertilizer phosphorus in phosphorus deficient soils of the Red

River Valley 2001, Journal of sugar beet research ISSN 0899-1502. Shellenberger, R. S. (1993) Taste Chemistry, Blackie Academic \& Professional: London, pp20-23.

Smis A .L. and J. Smith.(2002). Studies show P starters produced yields equal to or exceeding those produced by larger rates of $\mathrm{P}$ applied through broadcasting.2002.Bulletin No.42P8-10.

Sims, A.L., and L.J. Smith. (2001.) Early growth response of sugarbeet to fertilizer phosphorus in phosphorus deficient soils of the Red River Valley. Amer. Soc. Sug. Beet Res. In press.

Smith, J.A., R.G. Wilson, G.D. Binford and C.D. Yonts ( 2002). Tillage systems for improved emergence and yield of sugarbeets. Applied Engineering in Agriculture 18:6, 667-672.

Saccomani, M. Stevanato, P., Biancardi, E. (2007). Annual Beet Sugar Development Foundation Research Report p.20. www.ars.usda.gov/pandp/people/people.htm?personid=3728 . 